\title{
Öğretmen Adaylarında Güvengenliğin Yordayıcıları Olarak Temel Psikolojik İhtiyaçların Doyumu ve Bilinçli Farkındalık
}

\section{Satisfaction of Basic Psychological Needs and Mindfulness as Predictors of Assertiveness of Teacher Candidates}

\author{
Saadet ZÜMBÜL (iD , Araştırma Görevlisi, Afyon Kocatepe Üniversitesi, Eğitim Fakültesi, Rehberlik ve Psikolojik \\ Danışmanlık Ana Bilim Dalı, Afyonkarahisar/Türkiye, szumbul@aku.edu.tr
}

Yağmur SOYLU , Doç. Dr., Dokuz Eylül Üniversitesi, Buca Eğitim Fakültesi, Rehberlik ve Psikolojik Danışmanlık Ana Bilim Dalı, İzmir/Türkiye, yagmur.soylu@deu.edu.tr

Zümbül, S. ve Soylu, Y. (2021). Öğretmen Adaylarında Güvengenliğin Yordayıcıları Olarak Temel Psikolojik intiyaçların Doyumu Ve Bilinçli Farkındalık. Batı Anadolu Eğitim Bilimleri Dergisi, 12 (1), 116-132.

Geliş tarihi: 02.12.2020

Kabul tarihi: 30.04 .2021

Yayımlanma tarihi: 28.06.2021

Öz. Güvengenlik, bireyin etkileşime girdiği diğer kişilerin değerlerini ve haklarını yadsımadan kendi değeri ve hakkını da gözetecek şekilde iletişim kurabilme becerisi olarak tanımlanabilir. Eğitim fakültesi öğrencileri birer öğretmen adayları olarak kendilerini etkili bir şekilde ifade etme, kendi kararlarını alabilme, ailesi ve çevresi ile sağlıklı ve doyurucu iletişimler kurma gereksinimi duyabilmektedir. Bu araştırmanın amacı, temel psikolojik ihtiyaçların doyumu (özerklik ihtiyacı, yeterlik ihtiyacı, ilişkili olma intiyacı) ve bilinçli farkındalık değişkenlerinin öğretmen adaylarının güvengenlik düzeylerini yordama güçlerini incelemektir. Araştırmanın örneklemini, yaşları 18 ve 27 arasında değişen 246 'sı kadın ve 124 'ü erkek olmak üzere 370 öğretmen adayı oluşturmuştur. Veri toplama araçları olarak Kendini Belirleme Ölçeği, ihtiyaç Doyumu Ölçeği, Bilinçli Farkındalık Ölçeği ve Kişisel Bilgi Formu kullanıımıştır. Verilerin analizinde Adımsal Regresyon Analizi uygulanmıştır. Bulgulara göre sırasıyla özerklik ihtiyacı doyumu, bilinçli farkındalık ve yeterlik ihtiyacı doyumu değişkenleri öğretmen adaylarının güvengenlik düzeylerini anlamlı şekilde yordamışıı. Bu üç değişkenin ortak etkilerinin ise güvenlik düzeylerine ilişkin varyansın \% 50'sini açıkladığı tespit edilmiştir. Elde edilen bulgular literatür ışığında tartışılarak gelecekte yapılabilecek araştırmalar için öneriler sunulmuştur.

Anahtar Kelimeler: Güvengenlik, Temel psikolojik ihtiyaçlar, Bilinçli farkındalık, Öğretmen adayları.

\begin{abstract}
Assertiveness can be defined as the ability of an individual to communicate in a way that respects his / her own values and rights without denying the values and rights of other individuals with whom he / she interacts. As teacher candidates, students of the faculty of education may need to express themselves effectively, make their own decisions, and establish healthy and fulfilling communications with their family and environment. The aim of this study is to examine the predictive power of basic psychological needs satisfaction (the need for autonomy, the need for competence, the need to be relatedness) and the mindfulness variables in teacher candidates' assertiveness levels. The sample of the study consisted of 370 teacher candidates, 246 of whom were women and 124 were men, aged between 18-27. Self-Determination Scale, Need Satisfaction Scale, Mindful Attention Awareness Scale and Personal Information Form were used as data collection tools. Stepwise regression analysis was used to analyze the data. According to the findings, the variables of autonomy need satisfaction, mindfulness and competence need satisfaction significantly predicted the assertiveness levels of teacher candidates. It has been determined that the common effects of these three variables explain $50 \%$ of the variance regarding assertiveness levels. The obtained findings were discussed in the light of the literature, and suggestions were presented for future research.
\end{abstract}

Keywords: Assertiveness, Bacic psychological needs, Mindfulness, Teacher candidates. 


\section{Extended Abstract}

Introduction. Students of the faculty of education may need to express themselves effectively as candidates for teachers, make their own decisions, and establish healthy and fulfilling relationships with their family and environment. In addition, their communication with their students, colleagues and parents will be added to these interaction networks when they step into the teaching profession. Therefore, they are expected to have a number of social competencies for effective and healthy communication. In this context, it can be said that social interaction and therefore assertiveness are at the heart of the teaching profession. It is noted that the interaction that teachers, especially those who are just starting out in the profession, establish with their students is also important for their professional well-being (Schmidt, Klusmann, Lüdtke, Möller \& Kunter, 2017). When the literature is examined, it is thought that the satisfaction of their basic psychological needs and mindfulness may be associated with the ability to be assertiveness. In this direction, the aim of this research is to examine the predictor role of satisfaction of basic psychological needs and mindfulness on the level of assertiveness in teacher candidates.

Method. This research is a correlational study. The research universe consists of a total of 5796 teacher candidates, of whom 3622 (62.4\%) are women and 2174 (37.5\%) are men, who are studying in a total of 8 departments affiliated to the Faculty of Education of Dokuz Eylul University. A simple random sampling method, one of the probability-based sampling methods, was used to reach a set number of groups from the universe. The following steps were followed in this process: First, a list containing the departments of the faculty has been prepared. In the second stage, a table of random numbers was used to select the groups included in the list. At the last stage, branches belonging to the departments determined were selected by the draw method, which is a randomized method. As a result, a total of 370 students made up the sample group, $65.5 \%$ of whom were female $(n=246)$ and $33.5 \%(n=124)$ were male. In the study, Self-Determination Scale, Needs Satisfaction Scale, Mindful Attention Awareness Scale and Personal Information Form prepared by the researchers were used as data collection tools.

Results. Stepwise regression analysis was used to examine the predictive power of autonomy, competence and relatedness satisfaction and mindfulness variables on assertiveness. When standardized regression coefficients $(\beta)$ are examined to see variables that significantly predict the level of assertiveness, respectively, the need for autonomy $(\beta=.38)$, mindfulness $(\beta=.29)$ and the need for competence $(\beta=.21)$ seem to significantly predict the level of assertiveness of teacher candidates $\left(F_{(4-369)}=126.512, p<.01\right)$. However, it seems that the relatedness variable does not significantly predict the level of assertiveness of university students $(p>.05)$. The need for autonomy contained in the basic psychological satisfaction of needs alone explains $38 \%$ of the variance of the predicted variable. The mindfulness variable, which is in the second place in terms of its predictive power, increased the variance explained together with the need for autonomy to $48 \%$, while the mindfulness variable alone contributed $9 \%$. In the last step, the common effect of the variables of autonomy, mindfulness and competence explains $50 \%$ of the variance in students' assertiveness levels $\left(R=.716, R^{2}=.509\right)$. In the last step, the need for competence, which makes a significant contribution to the model, alone contributed $2 \%$.

Discussion and Conclusion. As a result, mindfulness with the satisfaction of the need for autonomy and competence has emerged as internal-psychological resources that predict teacher candidates' levels of assertiveness. It can be considered as an understandable finding that efforts to take part in or create environments that support autonomy contribute to the enhancement of the assertiveness skills of young adults and adults, one of the healthy communication skills. Mindfulness, on the other hand, can be considered to have positive effects on assertiveness, with its benefits on negative beliefs or automatic cognitions. Because when the level of mindfulness is high, individuals can move away from 
categorical cognitions and automatic thoughts labeled as good and bad, thus entering into more direct contact with the experience. This mental gap enables behavioral regulation by providing a time interval that allows harmonious and healthy responses between the stimulus (e.g. social experience where confident behavior should be displayed) and response (giving / not giving confident responses) that elicit automatic responses (Brown, Ryan \& Creswell, 2007; Thomas, 2011). According to the researches, individuals with higher level of mindfulness express themselves more frequently in various social situations and act with awareness (Dekeyser, Raes, Leijssen, Leysen \& Dewulf, 2008).

In light of the findings from the study, it is possible to provide researchers with some recommendations for future studies. It is very valuable to work on healthy communication skills with teacher candidates or teachers who are just starting the profession. Indeed, socially and emotionally competent teachers can develop supportive and encouraging relationships with their students, create a classroom climate that will encourage students' strengths, abilities, and inner motivation, guide students in conflict situations, and become a role model (Jennings \& Greenberg, 2009). In this study, the assertiveness skill, which is a healthy communication skill, and the basic psychological needs and mindfulness variables that reflect internal resources were examined. In addition to these, environmental and contextual variables can be examined in the studies to be done. In addition, correlational, experimental studies and cross-sectional patterns on assertiveness are relatively higher, while qualitative and longitudinal studies are almost absent. Future studies can contribute to the related literature by taking the pattern diversity into consideration. In addition to all these, it is necessary to emphasize the importance of university psychological counseling units based on the research results. It can be said that it is important to conduct orientation studies for new students in these units, various psychoeducation programs for assertiveness skills, and group counseling studies focused on interpersonal relationships. 


\section{Giriş}

Insanlar duyuşsal, bilişsel ve davranışsal olarak pek çok yönden gelişebilmek, yaşamlarını ve iyi oluşlarını sürdürebilmek için diğer insanlarla ilişki içinde olmaya ihtiyaç duymaktadır. Öyle ki bireyler kurdukları ilişkiler içinde var olup şekillenmektedir, bu doğrultuda diğerleriyle ilişkisi olmayan bir insandan söz etmek mümkün değildir (Cüceloğlu, 2014). Kişilerarası ilişkiler kurmak en temel intiyaçlardan olmakla birlikte bazı mesleklerde daha fazla önem kazanmaktadır ki öğretmenlik bu mesleklerden biridir. Öğretmenler öğrencileri, velileri, diğer meslektaşları ve okul yöneticileri ile sürekli etkileşim halindedir. Bu çok yönlü etkileşim, pek çok stresi de beraberinde getirebilmektedir. Özellikle mesleğe yeni başlayan öğretmenlerin, öğrencileri ile kurdukları etkileşimin mesleki iyi oluşları için de önemli olduğuna dikkat çekilmektedir (Schmidt, Klusmann, Lüdtke, Möller ve Kunter, 2017). Ayrıca süreğen sosyal ilişkiler içinde olmalarının yanında öğrencilerin sosyal beceriler kazanmalarında da temel rol modellerinden biri olmaktadırlar. Bu bağlamda öğretmenlerin sosyal becerilere ve sosyal yeterliklere sahip olmaları son derece önemli olduğu görülmektedir.

Sağlıklı ilişkiler kurmanın ve sürdürmenin en önemli göstergelerinden biri olan sosyal yeterlik, sosyal etkileşimde kişisel hedeflere ulaşırken aynı zamanda başkalarıyla olumlu ilişkiler sürdürme yeteneğini ifade eden şemsiye bir terimdir (Rubin ve Rose-Krasnor, 1992). Temelde, güvengenlik ve uyum sağlama olarak iki boyuttan oluşan bir yapı olarak ele alınmaktadır (Carstensen ve Klusmann, 2020). Güvengenlik, bireyin etkileşime girdiği diğer bireylerin insan olmaktan gelen değerlerini ve haklarını yadsımadan kendi değeri ve hakkını da gözetecek şekilde iletişim kurabilme becerisi olarak tanımlanabilir (Uz-Baş, 2012; Voltan, 1980). Bu beceri, tepkisel veya pasif davranışların aksine eşit bir ilişki kurma anlayışına dayanmaktadır. Bu anlamda bireyin kendini ve iletişim kurduğu kişilerin haklarını dikkate alarak kaygı duymaksızın dürüst bir şekilde kendini ifade edebilmesini yansıtan bir davranış şeklidir (Uz-Baş, 2012). Aynı zamanda bu etkileşimde intiyaçlarını ve hedeflerini de sürdürebilmelerine izin veren becerileri içinde barındırmaktadır (Carstensen ve Klusmann, 2020). Bu doğrultuda bireyin intiyaçlarını göz ardı etmesi ya da yıkıcı yollarla elde etmesi yerine fark etmesine ve sağlıklı yollarla doyum sağlamasını kolaylaştırmaktadır. Özellikle de büyüme, bütünleşme, sosyal gelişim ve iyi olmaya dair doğal insani eğilimleri mümkün kılan temel psikolojik ihtiyaçlara doyum sağlamada (CihangirÇankaya, 2009b; Ryan ve Deci, 2000) önemli bir kaynak görevi görebilir.

Temel psikolojik ihtiyaçlar, Öz Belirleme Kuramının (Self-Determination Theory, SDT) merkezi öneme sahip kavramlarından biridir (Ryan ve Deci 2017). SDT geniş bir çerçevede içsel motivasyon, öz düzenleme ve iyi oluş temelinde sağlıklı psikolojik gelişime ilişkin doğal süreçleri kolaylaştıran ya da bu süreöleri engelleyen sosyal-bağlamsal faktörlere odaklanmaktadır. Bu faktörlerle sağlıklı psikolojik gelişim arasındaki temel aracı değişken ise temel psikolojik intiyaçların karşılanıp karşılanmamasıdır (Ryan ve Deci, 2000; Ryan, Huta ve Deci, 2008). Kurama göre insanlar en etkili şekilde işlevsellik göstermek ve gelişmek için özerklik, yeterlik ve ilişkili olma olmak üzere üç temel psikolojik ihtiyaca sahiptir (Deci ve Ryan, 2000). Temel psikolojik intiyaçlar hem doyum hem de doyumsuzluk temelinde incelenmekte (Vansteenkiste, Ryan ve Soenens, 2020) ayrıca ihtiyaçların karşılanmasına sosyal çevre tarafından set çekildiği algısını yansıtan ihtiyacın engellenmesi temelinde de ele alınabilmektedir (Costa, Ntoumanis ve Bartholomew, 2015). Özerklik ihtiyacı, kişilerin kendi davranışlarını düzenlerken ne kadar özgür, istekli ve sorumlu hissettiklerini ifade eder. Karar alma ve eyleme geçme sürecinde bağımsız davranabilmesi, seçim ve irade duygusuyla kararlar alabilmesi bireylerin özerklik intiyacının doyumunu sağlamaktadır (Ryan ve Deci, 2002; Ryan vd., 2008; Toprak, 2014). Doyumsuzluk durumunda ise birey, istenmeyen bir yöne itilmiş hisseder ve çoğu zaman çatışma yaşar (Vansteenkiste vd., 2020). Yeterlik ihtiyacı, bireyin kendini etkili ve becerikli hissetme ile istediği sonuçları elde etme arzusunu yansıtır. Hem iç hem de dış çevresini iyi bir şekilde etkileme ve etkileşimde olma kapasitesidir. Kişi yeterlik ihtiyacına doyum sağlayamadığında etkisizlik, başarısızık ve çaresizlik duyguları yaşayabilir (Costa vd., 2015; Vansteenkiste vd., 2020). Son olarak, ilişkili olma intiyacı, bireylerin sosyal çevrelerindeki diğerlerine karşı güvenli bir aidiyet ve bağlılık duygusu hissetme derecesi olarak 
tanımlanır. Temelde bireyin başkaları ile bağlantılı olma ihtiyacıdır. (Cihangir-Çankaya, 2009a; Ryan ve Deci, 2002). ilişki olma ihtiyacının doyumsuzluğu, sosyal yabancılaşma, dışlanma ve yalnızık duygusunu beraberinde getirmektedir (Vansteenkiste vd., 2020). SDT'ye göre temel psikolojik ihtiyaçların doyumu büyüme, bütünleşme ve iyi oluş için bir ön koşul olmakla birlikte (Ryan vd., 2008) kişilerarası yeterliğin önemli yordayıcılarından biridir (Costa vd., 2015). Bu doğrultuda temel psikolojik intiyaçlarının doyumunun güvengenlik becerisiyle ilişkili olduğu düşünülmektedir. Bununla birlikte hem iyi oluş ve temel psikolojik intiyaç doyumuyla (Chang, Huang ve Lin, 2015; Ryan vd., 2008) hem de kişilerarası davranışlar (Dekeyser, Raes, Leijssen, Leysen ve Dewulf, 2008) ve sağlıklı iletişimi yansıtan çeşitli becerilerle (Jones, Bodie ve Hughes, 2019) yakından ilişkili bir diğer psikolojik yapı da bilinçli farkındalıktır.

Bilinçli farkındalık, dikkatin istemli olarak ve yargısız bir şekilde anlık deneyimlerin akışına yöneltilmesi olarak tanımlamaktadır (Kabat-Zinn, 2003). Temelde içsel deneyimlere yani duygularına ve bilişlerine tepkisel yanıtlar vermek yerine kabul edici bir tarzda yaklaşarak açık ve alıcı bir dikkat vermeyle ortaya çıkan farkındalığı ifade etmektedir (Brown ve Ryan, 2003). Böylesi bir farkındalık bireylerin sadece kendine ilişkin değil, daha geniş bir odaktaki farkındalığını yansıttığından bireyler ben merkezli bir bakış açısından çıkıp dış çevreyle ilişkilerinin de farkındalı̆̆ına ulaşabilir (Chang vd., 2015). Bilinçli farkındalığın iyi oluş ve sağlıklı psikolojik gelişimle yakından ilişkili olduğu pek çok çalışma ile kanıtlanmıştır (Brown ve Ryan, 2003; Keng, Smoski ve Robins, 2011). Bununla birlikte empati, aktif dinleme (Jones vd., 2019), destekleyici iletişim becerileri (Jones ve Hansen, 2015), sosyal-duygusal yeterlik (Dorman, 2015) gibi sağıklı iletişim kurma becerileriyle bağlantılı olan pek çok yapıyla da ilişkilidir. Bu doğrultuda bilinçli farkındalığın etkili ve sağlıklı bir iletişim biçimini yansıtan güvengenlik becerisiyle de ilişkili olabileceği akla gelmektedir. Diğer yandan negatif otomatik düşünceler (Frewen, Evans, Maraj, Dozois ve Partridge, 2007) ve ruminasyon (Coffey ve Hartman 2008) gibi olumsuz düşünme stilleri olan ilişkisi, bilinçli farkındalığın iletişim kurma sürecinde ortaya çıkabilecek olumsuz inançlar üzerinde de etkili olabileceğini düşündürmektedir. Nitekim güvengenlik düzeyinin düşük olmasının en çok dikkat çeken nedenlerinden biri, bireylerin sosyal ilişkilerinde kendilerine yönelik olumsuz yargılarının ve gerçek olmayan düşüncelerinin olmasıdır (Uz-Baş, 2012). Bilinçli farkındalık ise eleştirel olamayan, açık ve alııı bir zihin durumudur; bireylerin düşünceleri ve duygularını değiştirmeye, görmezden gelmeye ya da onlardan kaçmaya çalışmasını değil ortaya çıktıkça bu duygu ve düşünceleri gözlemlemesini içerir (Neff, 2003). Bu gözlemci tutum kişinin sıkıntı verici duygularına ve olumsuz düşüncelerine mesafe kazanabilmesini sağlamaktadır (Ögel, 2015).

\section{Araştırmanın Amacı}

Eğitim fakültesi öğrencileri birer öğretmen adayları olarak kendini etkili bir şekilde ifade etme, kendi kararlarını alabilme, ailesi ve çevresi ile sağlıklı ve doyurucu iletişimler kurma gereksinimi duyabilmektedir. Ayrıca öğretmenlik mesleğine adım attıklarında bu etkileşim ağlarına öğrencileri, meslektaşları ve velileri ile iletişimleri de eklenecektir. Dolayısıyla etkili ve sağlıkı iletişim için birtakım sosyal yeterliklere sahip olmaları beklenmektedir. Bu bağlamda sosyal etkileşimin öğretmenlik mesleğinin temelinde yer aldığı söylemek mümkündür. Özellikle mesleğe yeni başlayan öğretmenlerin, öğrencileri ile kurdukları etkileşimin mesleki iyi oluşları için de önemli olduğuna dikkat çekilmektedir (Schmidt vd., 2017). Örneğin yapılan bir çalışmaya göre, mesleğinde ilk yılları olan öğretmenlerde sosyal yeterliliğin temel boyutları olan güvengenlik ve uyum sağlama, duygusal tükenmişliğin negatif olarak yordayıcıları olarak bulunmuştur (Carstensen ve Klusmann, 2020). Dolayısıyla bu çalışmanın amacı, temel psikolojik ihtiyaçların doyumu (özerklik ihtiyacı, yeterlik ihtiyacı, ilişkili olma ihtiyacı) ve bilinçli farkındalık değişkenlerinin öğretmen adaylarının güvengenlik düzeylerini yordama düzeyini incelemeyi amaçlamaktadır. 


\section{Yöntem}

Bu araştırma, üniversite öğrencilerinde güvengenliğin yordayıcıları olduğu düşünülen temel psikolojik ihtiyaçların doyumu ve bilinçli farkındalık değişkenlerini incelemeyi amaçlayan korelasyonel bir araştırmadır.

\section{Araştırma Grubu}

Araştırmanın çalışma evrenini, Buca Eğitim Fakültesi'nin 8 farklı bölümünde öğrenimlerine devam eden 3622'si (\% 62.4) kadın ve 2174'ü (\% 37.5) erkek olmak üzere toplam 5796 öğretmen adayı oluşturmuştur. Araştırmanın evrenini temsil edebilecek uygun büyüklükteki örneklemi belirleyebilmek için kuramsal örneklem büyüklükleri tablosundan yararlanılmıştır. Tabloya göre \% $5^{\prime}$ lik örnekleme hatası ile 5000 kişilik bir evrenle araştırma yürütmek için gerekli örneklem büyüklüğü 357; 10000 kişilik evren için ise bu sayının 370 olması gerektiği belirlenmiştir (Yazıcıoğlu ve Erdoğan, 2004). Bu çalışmanın evrenini 5796 öğretmen adayı oluşturmuş ve veri kayıpları da olabileceği hesaba katılarak 370 katııımcıya ulaşmak amaçlanmıştır. Evrenden belirlenen sayıdaki örneklem grubuna ulaşmak amacıyla basit tesadüfi örnekleme yöntemi kullanılmıştır. İzlenen aşamalar şu şekildedir: Illk adımda eğitim fakültesi bölümlerinde yer alan anabilim dallarına ait bir liste oluşturulmuştur. İkinci adımda, listede yer alan anabilim dalları rastgele sayılar tablosu kullanılarak seçilmiştir. Son adımda belirlenmiş olan anabilim dallarından seçilecek şubeler, seçkisiz bir yöntem olan kura yöntemi ile belirlenmiştir. Böylece örneklem grubu, \% 65.5'ini kadın $(n=246)$ ve \% 33.5'sini $(n=124)$ erkek, toplam 370 öğrenciden oluşmuştur. Öğrencilerin yaş aralıkları 18-27 arasında değişmiştir. Örneklem grubuna ait tanıtıcı bilgiler Tablo 1'de gösterilmiştir.

Tablo 1.

Örneklem grubuna ait tanıtıcı bilgiler

\begin{tabular}{|c|c|c|c|}
\hline Tanıtıcı Bilgiler & & $f$ & $\%$ \\
\hline \multirow{3}{*}{ Cinsiyet } & Kadın & 246 & 66.5 \\
\hline & Erkek & 124 & 33.5 \\
\hline & Toplam & 370 & 100 \\
\hline \multirow{5}{*}{ Sinıf } & $1 . \sin ı f$ & 103 & 27.8 \\
\hline & 2.sinif & 91 & 24.6 \\
\hline & 3.sinıf & 71 & 19.2 \\
\hline & 4.sinif & 105 & 28.4 \\
\hline & Toplam & 370 & 100 \\
\hline \multirow{8}{*}{ Bölüm } & İngilizce Öğretmenliği & 63 & 17 \\
\hline & Sosyal Bilgiler Öğretmenliği & 64 & 17.3 \\
\hline & Bilgisayar Öğretmenliği & 39 & 10.5 \\
\hline & Zihinsel Engelliler Öğretmenliği & 32 & 8.6 \\
\hline & Okul Öncesi Öğretmenliği & 39 & 10.5 \\
\hline & Türkçe Öğretmenliği & 39 & 18.6 \\
\hline & Illköğretim Mat. Öğretmenliği & 64 & 17.3 \\
\hline & Toplam & 370 & 100 \\
\hline
\end{tabular}




\section{Veri Toplama Araçları}

\section{Kendini Belirleme Ölçeği (KBÖ)}

Kendini Belirleme Ölçeği üniversite öğrencilerinde güvengenlik düzeylerini değerlendirebilmek üzere Voltan-Acar ve Öğretmen (2007) tarafından geliştirilen ölçek toplam 28 madde ve çekingenlik ile güvengenlik olmak üzere iki alt boyuttan oluşmaktadır. KBÖ, 1 ile 6 arasında değişen bir puanlama cetveline dayanmaktadır. Alınabilecek en düşük puan 28 , en yüksek puan ise 168 'dir ve alınan puanlar yükseldikçe bireyin güvengenlik düzeyinin de artığı şeklinde yorumlanmaktadır. Ölçeğin doğrulayıcı faktör analizi bulguları göre alt ölçeklerin iç tutarlık güvenirlik katsayıları, çekingenlik boyutu için .83 ve güvengenlik boyutu için.78 olarak bulunmuştur. Toplam puana ilişkin katsayı ise .87 olarak raporlanmıştır. Bu araştırmadaki örneklem grubu için ölçeğin güvenirlik katsayısı da .87 olarak bulunmuştur.

\section{ihtiyaç Doyumu Ölçeği (iDö)}

îhtiyaç Doyumu Ölçeği, Öz Belirleme Kuramına dayalı olarak bireylerin özerklik, yeterlik ve ilişkili olma ihtiyaçlarına doyum sağlama düzeylerini değerlendirmek amacıyla Deci ve Ryan (1991) tarafından geliştirilmiştir. Ölçek bireyin üç temel psikolojik ihtiyacını ölçen üç alt boyut ve 21 maddeden oluşmaktadır. Her madde 7'li dereceleme kullanılarak puanlanmaktadır. Ölçekten elde edilebilecek puanlar, ölçeğin tümü için 21-147, Özerklik alt ölçeği için 7-49, Yeterlik alt ölçeği için 6-42, iliş̧kili Olma alt ölçeği için 8-56 arasında değişmektedir. Ölçekten alınan yüksek puanlar bireylerin ilgili temel psikolojik ihtiyacına doyum sağladığını, düşük puanlar ise ihtiyaç doyumunun düştüğünü göstermektedir. Doğrudan ifadeler ile tersine dönmüş ifadelerin puanlanması ayrı ayrı yapıldıktan sonra hem toplam puan hem de alt boyutlar temelinde puanlar elde edilmektedir. Ölçeğin toplam puana ve alt ölçeklere yönelik iç tutarlık katsayıları 250 öğrencinin yer aldığı bir örneklem üzerinde hesaplanmıştır. İç tutarlık katsayıları alt ölçekler için sırasıyla $.71, .60$, ve .74 ve toplamda ise .83 olarak bulunmuştur. Ölçeğin iki hafta arayla uygulanmasıyla elde edilen korelasyon katsayıları ise .89; alt ölçekler için sırasıyla .82, .80 ve .81'dir (Bacanlı ve Cihangir-Çankaya, 2003). Bu araştırmadaki örneklem grubu için ölçeğin güvenirlik katsayıları, alt ölçekler için sırasıyla $.77, .57$, ve .72 ve toplamda ise .84 olarak hesaplanmıştır.

\section{Bilinçli Farkındalık Ölçeği (BiFö)}

Bilinçli Farkındalık Ölçeği (BiFÖ), şimdiki zamanda yaşanan deneyimlere ilişkin açık bir farkındalık ve dikkati sürdürme becerisini değerlendirme amacıyla geliştirilmiştir (Brown ve Ryan, 2003). Toplam 15 maddeden oluşan ölçek, toplam puan vermekte ve 1 ile 6 arasında değişen bir puanlama ölçeğiyle derecelendirilmektedir. Ölçekten alınabilecek en düşük puan 15, en yüksek puan 90'dır. Yüksek puanlar bilinçli farkındalık düzeyinin de yüksek olduğunu şeklinde yorumlanmaktadır. Türkçeye uyarlama çalışmasında, 15 madde için madde-toplam korelasyonun .436 ile .682 arasında değiştiği ve Cronbach Alpha iç tutarlılık katsayısının .80 olduğu raporlanmıştır. Üç hafta ara yapılan testtekrar test yönteminden elde edilen güvenirlik katsayısı ise .86 olarak bulunmuştur (Özyeşil, Arslan, Kesici ve Deniz, 2011). Bu araştırmadaki örneklem grubu için ölçeğin güvenirlik katsayısı .78 olarak hesaplanmıştır.

\section{Kişisel Bilgi Formu}

Araştırmacılar tarafından oluşturulmuş ve katılımcıların cinsiyeti, öğrenim gördükleri bölüm ve sınıf düzeylerine ilişkin sorular yer almıştır. 


\section{Verilerin Toplanması}

Veriler, ilgili fakültelerin belirlenen sınıflarında sorumlu öğretim üyelerinden izin alınarak ders ortamında gerçekleştirilmiştir. Öğrencilere çalışma hakkında kısaca bilgi verildikten sonra gönüllü olarak çalışmaya katılmak isteyen öğrenciler ile ölçek uygulaması gerçekleştirilmiştir. Araştırmacı öğrencilerin sorularına yanıt vermek için sınıfta bulunmuştur. Ölçeklerin cevaplaması yaklaşık 15-20 dakika sürmüştür.

\section{Verilerin Analizi}

Araştırmada elde edilen verilerin çözümlenmesinde çoklu doğrusal regresyon analizi kullanılmıştır. Öncelikle çoklu doğrusal regresyon analizinin doğru sonuçlar verebilmesi için gerekli sayıltılar incelenmiştir. Bu amaçla ilk olarak puanların normal dağılıp dağılmadığı çarpıklık-basıklık tabloları ve normallik testi ile sınanmıştır. Çarpıklık-basıklık değerlerinin \pm 1 aralığında olmasıyla verilerin normal dağılım gösterdiği sonucuna ulaşılmıştır. Yapılan Kolmogorov-Smirnov testi de verilerin normal dağılıma uygunluğunu $(p>.05)$ desteklemiştir. Regresyon işleminin doğru sonuçlar verebilmesi için yordanan değişkenler birbirinden bağımsız olmalıdır yani değişkenler arasında .80 - .90 gibi yüksek düzeyde ilişkiyi içeren çoklu bağlantılık (multicolinearity) sorunu bulunmamalıdır (Can, 2014). Incelenen Pearson Momentler Çarpım Korelasyonu analizi sonucunda, en yüksek ilişkinin özerklik intiyacı ve güvengenlik arasında $(r=.62, p<.01)$ olduğu ve bunun da .80 'den düşük bir değer aldığı görülmüştür. Çoğlu bağlantılık sayıltısı ayrıca Varyans Büyütme Faktörü (VIF) ve Tolerans (Tolerance) ile kontrol edilmiştir. VIF değerinin 10'dan küçük, Tolerans değerinin ise .2'den büyük olması, çoklu bağlantılığa dair bir sorun olmadığına işaret etmektedir (Can, 2014). VIF değerlerinin 1.252 ile 1.550 arasında değiştiği, Tolerans değerlerinin ise .799 ile .645 arasında değiştiği gözlenmiş ve çoklu bağlantılık sorununun olmadığı tespit edilmiştir. Çok değişkenli normallik ve uç değerler için Mahalanobis Distance değerleri incelenmiştir. Sınır değerlerini belirlemek için, Mahalanobis uzaklık değerlerini belirleme yollarından biri olan Kay-Kare dağılım tablosu kullanılmıştır. Kay-Kare dağılım tablosu, regresyona giren bağımsız değişken sayısını serbestlik derecesi alan kay kare değerini ölçüt almaktadır (Can, 2014). Tabloya göre bağımsız değişken sayısı 4 olan bir regresyon modelinde, $p=.01$ düzeyinde, Mahalanobis değeri 13.277 'dir. Bu değer ölçüt alınarak çok değişkenli normallik sayıltısını ihlal eden herhangi bir uç değere tespit edilmemiştir. Regresyon analizinin yapılması için gerekli sayıltıların incelenmesi ve karşılanmasıyla regresyon analizi gerçekleştirilebilmiştir. Verilerin analizinde anlamlılık değeri $p<.05$ olarak kabul edilmiştir.

\section{Bulgular}

\section{Betimleyici İstatistikler}

Araştırmanın bağımlı değişkeni güvengenlik düzeyi, bağımsız değişkenleri ise özerklik, yeterlik ve ilişkili olma ihtiyacı doyumu ile bilinçli farkındalıktır. Bağımlı ve bağımsız değişkenlerine ilişkin aritmetik ortalama, standart sapma, minimum ve maksimum değerler Tablo 2'de verilmiştir.

Tablo 2.

Bağımlı ve bağımsız değişkenlere ilişkin aritmetik ortalama, standart sapma, minimum ve maksimum değerler

\begin{tabular}{lcccc}
\hline Değişkenler & $\overline{\mathbf{X}}$ & Ss & min. & max. \\
\hline 1.Güvengenlik & 114.34 & 19.69 & 51 & 165 \\
2.Özerklik & 35.37 & 7.18 & 10 & 49 \\
3.Yeterlik & 27.91 & 5.39 & 8 & 41
\end{tabular}




$\begin{array}{lcccc}\text { 4.ilişkili Olma } & 41.73 & 7.29 & 14 & 56 \\ \text { 5.Bilinçli Farkındalık } & 58.32 & 10.14 & 30 & 84\end{array}$

Araştırmada ele alınan güvengenlik düzeyi ile özerklik, yeterlik, ilişkili olma ihtiyacı doyumu ve bilinçli farkındalık değişkenleri arasında ilişki Pearson Momentler Çarpım Korelasyonu Analizi ile incelenmiştir. Elde edilen bulgular Tablo 3'te verilmiştir.

Tablo 3.

Bağımlı ve bağımsız değişkenler arasındaki korelasyon değerleri

\begin{tabular}{|c|c|c|c|c|c|}
\hline Değişkenler & 1 & 2 & 3 & 4 & 5 \\
\hline 1.Güvengenlik & - & & & & \\
\hline 2.Özerklik & $.623 * *$ & - & & & \\
\hline 3.Yeterlik & $.539 * *$ & $.547^{* *}$ & - & & \\
\hline 4.iliş̧kili Olma & $.412 * *$ & $.511 * *$ & $.446 * *$ & - & \\
\hline 5.Bilinçli Farkındalık & $.552^{* *}$ & $.449 * *$ & $.432^{* *}$ & $.269 * *$ & - \\
\hline
\end{tabular}

Not. ${ }^{*} p<.05,{ }^{* *} p<.01$.

Tablo 3 incelendiğinde, güvengenlik düzeyi ile özerklik ihtiyacı doyumu $(r=.62, p<.01)$, yeterlik intiyacı doyumu $(r=.54, p<.01)$, ilişkili olma ihtiyacı doyumu $(r=.41, p<.01)$ ve bilinçli farkındalık $(r=$ $.55, p<.01$ ) arasında orta düzeyde, pozitif yönde ve anlamlı ilişkiler görülmüştür. Bağımsız değişkenlerin kendi aralarındaki ilişki incelendiğinde ise en yüksek ilişkinin yeterlik ihtiyacı doyumu ile özerklik ihtiyacı doyumu $(r=.55, p<.01)$ arasında olduğu; en düşük ilişkinin ilişkili olma ihtiyacı doyumu ile bilinçli farkındalık $(r=.27, p<.01)$ arasında olduğu ve bu ilişkilerin de pozitif yönde ve anlamlı ilişkiler olduğu görülmüştür.

\section{Güvengenliği Yordayan Değişkenlerin İncelenmesi}

Özerklik, yeterlik ve ilişkili olma intiyacı doyumu ile bilinçli farkındalık değişkenlerinin güvengenliği yordama gücünü incelemek için Adımsal Regresyon Analizi kullanılmıştır. Elde edilen sonuçlara Tablo 4'te yer verilmiştir.

Tablo 4.

Güvengenliğin temel psikolojik intiyaçların doyumu ve bilinçli farkındalık değişkenleri tarafından yordanmasına ilişkin Adımsal Regresyon Analizi sonuçları

Korelasyonlar

\begin{tabular}{|c|c|c|c|c|c|c|c|c|c|c|c|}
\hline $\begin{array}{l}\frac{\overline{0}}{0} \\
\frac{0}{2}\end{array}$ & Değişkenler & B & $\mathrm{SH}_{\mathrm{B}}$ & $\beta$ & $\mathrm{T}$ & $\mathrm{R}$ & $\mathrm{R}^{2}$ & $\Delta$ & $\mathrm{F}$ & $\begin{array}{c}\text { İkili } \\
\text { Korelasyon }\end{array}$ & $\begin{array}{c}\text { Kısmi } \\
\text { Korelasyon }\end{array}$ \\
\hline 1 & $\begin{array}{l}\text { (Sabit) } \\
\text { Özerklik }\end{array}$ & $\begin{array}{c}53.872 \\
1.709\end{array}$ & $\begin{array}{l}4.037 \\
.112\end{array}$ & $\begin{array}{c}- \\
.623\end{array}$ & $\begin{array}{l}13.345^{* *} \\
15.286^{* *}\end{array}$ & .623 & .388 & .388 & $233.652 * *$ & $.623^{* *}$ & $.623^{* *}$ \\
\hline 2 & $\begin{array}{l}\text { (Sabit) } \\
\text { Özerklik }\end{array}$ & $\begin{array}{c}30.068 \\
1.289\end{array}$ & $\begin{array}{l}4.737 \\
.115\end{array}$ & $\begin{array}{c}- \\
.470\end{array}$ & $\begin{array}{c}6.348^{* *} \\
11.175^{* *}\end{array}$ & .694 & .482 & .093 & $170.452^{* *}$ & $.623 * *$ & $.504^{* *}$ \\
\hline
\end{tabular}




\begin{tabular}{|c|c|c|c|c|c|c|c|c|c|c|c|}
\hline \multirow{4}{*}{3} & $\begin{array}{l}\text { Bilinçli } \\
\text { Farkındalık }\end{array}$ & .663 & .082 & .342 & $8.123^{* *}$ & \multirow{4}{*}{.713 } & \multirow{3}{*}{.509} & \multirow{3}{*}{.028} & \multirow{3}{*}{$126.512^{* *}$} & \multirow{2}{*}{$\begin{array}{l}.552^{* *} \\
.623^{* *}\end{array}$} & \multirow{2}{*}{$\begin{array}{l}.390 * * \\
.399 * *\end{array}$} \\
\hline & $\begin{array}{l}\text { (Sabit) } \\
\text { Özerklik }\end{array}$ & $\begin{array}{c}23.414 \\
1.041\end{array}$ & $\begin{array}{l}4.844 \\
.125\end{array}$ & $\begin{array}{c}- \\
.379\end{array}$ & $\begin{array}{l}4.834^{* *} \\
8.323^{* *}\end{array}$ & & & & & & \\
\hline & $\begin{array}{l}\text { Bilinçli } \\
\text { Farkındalık }\end{array}$ & .570 & .082 & .294 & $6.946 * *$ & & & & & $.552 * *$ & $.341^{* *}$ \\
\hline & Yeterlik & .746 & .165 & .205 & $4.529 * *$ & & & & & $.539 * *$ & $.230 * *$ \\
\hline
\end{tabular}

Not. ${ }^{*} p<.05,{ }^{* *} p<.01$.

Tablo 4'e göre, güçleri bakımından sırasıyla özerklik ihtiyacı doyumu $(\beta=.38)$, bilinçli farkındalık $(\beta=.29)$ ve yeterlik ihtiyacı doyumu $(\beta=.21)$ değişkenleri, öğretmen adaylarının güvengenlik düzeyi puanlarını istatistiksel olarak anlamlı düzeyde yordamıştır $\left(F_{(4-369)}=126.512, p<.01\right)$. Bununla birlikte ilişkili olma ihtiyacı doyumunun ise öğretmen adaylarının güvengenlik düzeyi puanlarını anlamlı şekilde yordamadığı görülmüştür $(p>.05)$. Güvengenlik üzerindeki varyansın \% 38'i, özerklik ihtiyacı doyumu tarafından açıklanmıştır. Yordayıcı gücü bakımından ikinci sırada bulunan bilinçli farkındalık değişkeni, özerklik ihtiyacı ile birlikte açıklanan varyansı \% 48'e yükseltirken, tek başına açıklanan varyansa \% 9'luk bir katkı sağlamıştır. Son adımda özerklik ihtiyacı doyumu, bilinçli farkındalık ve yeterlik ihtiyacı doyumu değişkenlerinin ortak etkisinin öğrencilerin güvenlik düzeylerine ilişkin varyansın \% 50'sini açıkladıkları sonucuna ulaşıımıştır $\left(R=.716, R^{2}=.509\right)$. Son adımda modele anlamlı bir yordayıcı olarak dahil olan yeterlik intiyacı doyumu ise varyansa \% $2^{\prime}$ lik bir katkı sağlamıştır.

\section{Tartışma, Sonuç ve Öneriler}

Bu çalışmanın amacı özerklik, yeterlik ve ilişkili olma ihtiyacı doyumu ve bilinçli farkındalık değişkenlerinin, öğretmen adaylarının güvengenlik düzeylerini yordama güçlerini incelemektir. Araştırmadan elde edilen bulgulara göre, özerklik ihtiyacı doyumu, bilinçli farkındalık ve yeterlik ihtiyacı doyumunun ortak etkisi öğrencilerin güvenlik düzeylerine ilişkin varyansın \% 50'sini açıklamıştır. Temel psikolojik intiyaç doyumu alt değişkenleri içerisinde yer alan özerklik ihtiyacı doyumu, tek başına yordanan değişkendeki varyansının \% 38'ini açıklamasıyla modeldeki en güçlü yordayıcı olarak ortaya çıkmıştır.

Özerklik, en dikkat çeken ve araştırılan ihtiyaçların başındadır. Araştırmacılar bunu özerkliği destekleyen faktörlerin yeterlik ve ilişkili olma ihtiyacını karşılamayı da kolaylaştırabilmesine dayandırmıştır (Vansteenkiste vd., 2020). Kuramda özerklik ihtiyacı, kişinin kendi eylemlerinin başlatıcısı ve düzenleyicisi olma yönündeki temel ihtiyacını yansıtır (Özdemir ve Çok, 2011). Özerk olarak karar verme sürecinde birey hem kendi isteklerinin hem de eylemlerini seçme hakkının olduğunun farkındadır. Böylelikle eylemlerini isteyerek ve onaylayarak seçmektedir. Bu doğrultu da seçimlerinin ve davranışlarının sorumluluğunu üstlenip gerektiğinde bunları savunabilecek konumdadır (Kocayörük, 2012). Diğer yandan özerklik ihtiyacı karşılanmadığında ise bireyler duygularından kaçınabilir, kontrol etmeye dayanan düzenleme stratejilerini kullanabilir, diğerleriyle ilişkisinde başkalarını memnun etme ve onaylarını almaya dayalı etkileşimler içine girebilir (Vansteenkiste vd., 2020). Tüm bunlar özerklik ihtiyacını karşılayan bireylerin güvengen davranışlar ortaya koyabilme olasılıklarının daha yüksek olduğunu düşündürmektedir. Öyle ki güvengen bireyler düşünce duygu ve bireysel haklarının farkındadır, bunları ortaya koyarken sorumluluk alır, anksiyete duymaksızın kendini açık ve dürüst bir tarzda aynı zamanda diğer bireylerin düşüncelerine, duygularına ve haklarına saygılı bir şekilde ifade ederler (Uz-Baş, 2012). 
Güvengenlik gibi sağlıklı iletişim kurma becerilerinin oluşumunun, erken gelişimsel dönemlere dayandığını destekleyen kuramsal dayanaklar bulunmaktadır. Bu kuramsal dayanakların en temel olanları gelişim kuramları ve bağlanma kuramlardır. Psikososyal Gelişim Kuramı'nda bireylerin ilk iki gelişim basamağını 'güven' ve 'özerklik' oluşturmuştur. Bu dönemlerde bebek, bakım verenlerin düzenli olarak intiyaçlarına duyarlı ve cevap verebilir olduğunu fark ederse temel güven duygusu kazanmaktadır. Kendi eylemlerini düzenleyebilme imkânı verildiğini ve desteklendiğini fark ettiğinde ise özerklik duygusu gelişmektedir (Erikson, 1980). Güven ve özerkliğin hem kendisi hem de çevresi ile ilgili ilk algıları şekillendirmesi, bireyin ileride çevreyle kuracağı iletişimin de temellerini oluşturacaktır. Güvengenlik de hem bireyin kendisi hem de çevresiyle sağlıklı ilişkiler kurmasına olanak veren bir beceridir. Bu noktada özerkliği ve sosyalleşmeyi destekleyen ebeveyn tutumlarının önemli olduğu söylenebilir. Voltan-Acar, Arıcıoğlu, Gültekin ve Gençtanırım (2008) çalışmasında anne-babasının tutumlarını daha demokratik olarak algılayan üniversite öğrencilerinin güvengenlik düzeyinin daha yüksek olduğu sonucuna ulaşılmıştır. Demokratik tutuma sahip ebeveynler karar verme süreçlerine çocuklarını da dahil ederler, ailede gerekli düzeyde bir kontrol ortamı olmasının yanında özerkliği destekleyici bir iklim mevcuttur (Özdemir ve Çok, 2011). Görülmektedir ki erken dönem yaşantılar, güvengenlik üzerinde etkili olan özerklik ihtiyacında oldukça önemli bir rol oynamaktadır. Bununla birlikte sadece gelişimin ilk basamakları değil ergenlik ve yetişkinliğe geçiş dönemi olarak kabul edilen beliren yetişkinlik döneminde de özerkliği destekleyen bir çevrenin güvengenlik üzerinde etkili olacağı düşünülmektedir. Nitekim güvengenlik öğrenilebilen ve geliştirilebilen bir beceridir (Uz-Baş, 2012). Yaşam boyu gelişimciler, erken yaşantıları gelişimin önemli destekleyicileri olarak kabul ederken; geç yaşantıların önemini inkâr etmemektedir (Santrock, 2014). Özerkliği destekleyici ortamlar bireylerin düşüncelerini, ilgilerini, değer verdiklerini önemsemeyen bir çevreyi ifade etmektedir (CihangirÇankaya, 2009b). Böylesi bir özerklik desteği, ergenler ve genç yetişkinlerin özerklik ihtiyaçlarına doyum sağlamalarında kolaylaştırıcı olabilir. Yapılan bir çalışma, üniversite öğrencilerinin yetişkin olma algıları ile özerklik ihtiyaçlarının örtüştüğünü göstermiştir. Öğrencilerin yarıdan fazlası yetişkin olmayı kendi eylemlerinin ortaya çıkardığı sonuçların sorumluluğunu almak, kendi inançlarına ve değerlerine karar vermek, ebeveynlerle eşit bir yetişkin olarak ilişki kurmak anlamına geldiğini belirtmişlerdir (aktaran. Santrock, 2014). Özetle, özerklik ihtiyacı doyumunda hem gelişimsel koşullar ve ebeveyn tutumları hem de özerkliği destekleyici çevrenin, güvengen davranışları artırmada katkı sağlayabileceği söylenebilir. Temel psikolojik intiyaçlarına doyum sağlayan yaşantılar içinde girebilen bireyler, ilişkilerinde daha iyi işlev gösterebilir (Costa vd., 2015).

Araştırmanın bulgularına göre güvengenlik düzeyini yordayan ikinci önemli değişken bilinçli farkındalıktır. Özerklik intiyacı başta olmak üzere temel psikolojik intiyaçların doyumu birey tarafından özgürce ve isteyerek gerçekleştirilir (Ryan vd., 2008). Bireyler isteklerinin ve duygularının farkındalığına sahip değillerse düşünceleri, duyguları ve davranışları üzerinde kontrol sahibi de değildir. Bu aynı zamanda seçimlerinin özgür olmadığına işaret etmektedir (Soysal, Bodur ve Gökben Hızlı, 2005). Bu anlamda psikolojik ihtiyaçlarının daha fazla farkında olan bireylerin ihtiyaçlarını gidermeye yönelik güvengen adımlar atabileceği söylenebilir. Basit ifadeyle bilinçli farkındalık, şimdi zamanda gerçekleşen tüm deneyimlere geçmiş, gelecek ya da çeşitli yargıların etkisinden arınmış olarak duygu, düşünce, duyum ve ilişkisel olarak tam anlamıyla katılmaktır. Bireyler bilinçli farkında olduklarında, hem kendilerinin ve içinde oldukları durumların daha net bir farkındalığına erişebilirler böylece daha fazla seçeneğe sahip ve daha açık bir dikkatlilikle hareket edebilme yeteneğine de sahip olabilirler. Tüm bunlar bilinçli farkındalığın gelişmiş yürütücü işlevsellik, daha iyi öz düzenleme, daha fazla özerklik ve daha olumlu ilişkiler kurma kapasiteleri ile ilişkili olduğuna işaret etmektedir (Brown, Ryan ve Creswell, 2007). Yapılan bir çalışmada hem temel psikolojik ihtiyaçların doyumu hem de bilinçli farkındalık düzeyi psikolojik iyi oluş boyutlarından biri olan diğerleriyle olumlu ilişkiler kurmanın anlamlı bir yordayıcısı olarak bulunmuştur (Chang vd., 2015).

Sağlıklı bir iletişim becerisi anlamına gelen güvengenlik becerilerinin bazı bireylerde daha az olmasının nedenlerine ilişkin farklı açıklamalar mevcuttur. Bunlardan en çok üzerinde durulanları ise bireylerin sosyal ilişkilerine ve kendine yönelik olumsuz inançları ile güvengenlik becerilerini 
öğrenmemiş olmalarıdır. Insanlar benliklerine ya da yaşadıkları olaylara dair gerçekçi olmayan veya negatif bilişlere sahip olduklarında güvengen olma becerileri olumsuz etkilenmektedir. Bireyler güvengen bir şekilde kendini ortaya atmaya hakkı olmadığına (Uz-Baş, 2012) ya da bunun uygunluğuna veya doğruluğuna inanmakta (Corey, 2015) zorluk yaşayabilmektedir. Bu nedenle etkileşimde geri çekilip pasif ya da boyun eğici olabilir ya da saldırgan tepkiler verebilirler. Bunlar güvengenliğin tam tersi tepkilerdir. Güvengen davranış, pasif veya agresif davranışların aksine başkalarının kişisel haklarına müdahale etmeden bireyin kendini doğrudan ve dürüst bir şekilde ifade etmesidir (Zhukov, 2020). Bilinçli farkındalık, bu olumsuz inançlar ya da otomatik bilişler üzerindeki faydalarıyla da güvengenlik üzerinde olumlu etkilere sahip olabilir. Çünkü bilinçli farkındalık düzeyi yüksek olduğunda bireyler, iyi-kötü gibi etiketlenen kategorik bilişler ve otomatik düşüncelerden uzaklaşabilir böylece yaşanan deneyimle daha doğrudan bir temas içine girebilirler. Bilinçli farkındalığın temel işlevlerinden birinin içsel deneyimlerle araya sağlıklı bir mesafe koyabilme ile doğrudan temas edebilme arasında işleyen 'zihinsel bir boşluk' kazandırmasıdır. Bu zihinsel boşluk, otomatik tepkileri ortaya çıkaran uyaran (örn. güvengen davranış sergilenmesi gereken sosyal deneyim) ve yanıt (güvengen yanıtlar verme/vermeme) arasında uyumlu ve sağlıklı tepkiler vermeye olanak tanıyan bir zaman aralığı sağlayarak davranışsal düzenlenmeyi olanaklı kılmaktadır (Brown vd., 2007; Thomas, 2011). Yapılan araştırmalara göre bilinçli farkındalık düzeyi daha yüksek olan bireyler, çeşitli sosyal durumlarda kendilerini daha sık ifade etmekte ve farkındalıkla hareket etmektedir (Dekeyser vd., 2008). Ayrıca öğretmenlerin sosyal-duygusal yeterliklerini geliştirmede bilinçli farkındalık eğitiminin olumlu etkilerine de dikkat çekilmiştir (Dorman, 2015).

Bilinçli farkındalık arzuları anlama, ihtiyaçları ve değerleri dikkate almayla bireyin içsel deneyimleriyle daha iyi bir bağlantı kurmalarını olanaklı hale getirmektedir (Brown vd., 2007). Bu doğrultuda yüksek bilinçli farkındalığa sahip bireyler, temel psikolojik ihtiyaçlarını da daha iyi duyumsayabilir. Yapılan bir araştırmada temel psikolojik intiyaç doyumunun, bilinçli farkındalık ve iyi oluş arasında aracı değişken rolü üstlendiği ortaya çıkmıştır (Chang vd., 2015). Bu çalışmada da temel psikolojik intiyaç doyumu ve bilinçli farkındalık birbirleriyle pozitif yönde anlamlı ilişkilere sahiptir ve ortak etkileri güvenlik düzeyinde önemli bir varyans açıklamıştır. Bu anlamda bilinçli farkındalık ve temel psikolojik intiyaç doyumu birbirlerini besleyen psikolojik yapılar olabilir. Öyle ki araştırmacılar bilinçli farkındalığı artırmanın temel psikolojik intiyaçları karşılamayı kolaylaştırabileceğine işaret etmiştir (Ryan vd., 2008). Şimdiki anda tam anlamıyla var olmak ve deneyime tüm dikkatiyle katılmak bireylerin yaptığı işleri yargılaması veya olumsuz atıflarda bulunması yerine işini tamamlamaya odaklanması ve bundan zevk almaya başlamasını da beraberinde getirebilir. Böylesi bir dikkat regülasyonu, kaygılı şekilde performansını değerlendiren bireylerin yeterlilik ihtiyaçlarına doyum sağlamalarına yardımcı olabilir (Chang vd., 2015).

Araştırmanın bir diğer bulgusuna göre yeterlik intiyacı doyumu güvenlik düzeyinin anlamlı bir yordayıcısıdır. Yeterlik ihtiyacı, bireylerin giriştiği eylemlerde kendini etkili hissetmesini, gerekli veya yeterli yeteneklere sahip olduğu ve amaçladığı sonuçlara ulaşabileceği inancını içermektedir (Weinstein ve DeHaan, 2014, s. 8). Bu doğrultuda yeterlik ihtiyacı doyumunun güvengenlik ile ilişkisi, bireylerin etkileşimlerinde güvengen davranışlar sergilerken kendini ne kadar etkili hissettiği, gerekli becerilere sahip olup olmadığı ve kendini uygun bir şekilde ifade edip edemeyeceği inançlarını yansıtabilir. Öyle ki güvengen olmayan davranışların olası nedenleri arasında olumsuz inançların yanında kendini ifade etmeye dayanan davranışsal becerileri eksikliklerinin de olabileceği göz ardı edilmemelidir (Uz-Baş, 2012). Sağılıkı iletişim kurmak için gerekli becerilere sahip olup kendini yetkin gören bireylerin daha güvengen olacağı akla yakın görünmektedir. Dahası her bir psikolojik ihtiyacın güvengenlik ile bağlantılı olduğu düşünebilir. Temel psikolojik intiyaçlarına doyum sağladıklarını hisseden bireyler, kişilerarası iletişimde etkileşimi başlatabilir (özerklik), duygu ve düşüncelerini uygun şekilde iletmede becerikli olabilir (yeterlik) ve diğer bireylere duygusal destek sunabilir (ilişkili olma). Tüm bunlar, güvengenliğin de içinde yer aldığı kişilerarası yetkinliğin bir göstergesi olarak kabul edilir (Costa vd., 2015). 
Araştırmanın dikkat çeken son bulgusu, ilişkili olma ihtiyacının güvengenlik düzeyi üzerinde anlamlı bir yordama gücünün olmamasıdır. Temelde özerklik ve yeterlik ihtiyacı daha fazla dikkat çeken ve olumlu sonuçlarla faydası raporlanan değişkenler olmuştur (Deci ve Ryan, 2013; Ryan ve Deci, 2000). Ancak ilişkili olma ihtiyacına doyum sağlama da içsel motivasyonu destekleyen önemli bir faktör olarak ele alınmaktadır. Örneğin öğretmenler öğrencileriyle ve meslektaşlarıyla bağlantılı olmanın mesleki motivasyonlarının önemli bir parçası olduğunu bildirmişlerdir (bkz. Klassen, Perry ve Frenzel, 2012). iliş̧kili olma ihtiyacının temellerinde erken dönem bağlanmanın olduğu ve bu doğrultuda içsel motivasyonun da güvenlik ve ilişkili olma duygusuyla güçlenmiş bağlamlarda gelişmesinin daha muhtemel olduğunu varsayılmıştır (Ryan ve Deci, 2000). Öyle ki ilişkili olma ihtiyacı, bireyin diğer insanlarla bağlantıda olma ve yer aldığı sosyal çevreye ait olma hissini yansıtmaktadır (Kermen ve Sarı, 2014). Bu doğrultuda sonuçlara dair olası bir neden, üniversite öğrencilerinin birçoğunun eğitim görmek için başka bir şehre yerleşmesi ve kendilerini bu yeni şehre ait hissetmekte zorluklar yaşıyor olabilecekleridir. Nitekim ilişkili olma intiyacına doyum sağlayan yaşantılar, çevreyle bağlantılı ve ait hissetme ile paraleldir. Sonuç olarak, özerklik ve yeterlik ihtiyacı doyumu ile bilinçli farkındalık öğretmen adaylarının güvengenlik düzeylerini yordayan içsel-psikolojik kaynaklar olarak ortaya çıkmıştır.

Araştırmanın sonuçları yorumlanırken belli sınırlılıklar göz önünde bulundurulmalıdır. Bu çalışma eğitim fakültesi öğrencileriyle gerçekleştirilmiştir ve tüm üniversite öğrencilerine ya da öğretmenlere genellemek doğru olmamaktadır. Korelasyonel bir araştırma deseninde yürütüldüğü için bulgulardan nedensel değil ilişkisel çıkarımlar yapılabilmektedir. Her ne kadar araştırmadaki kadın ve erkek katılımcıların oranı, çalışma evrenindeki oranlarla örtüşse de kadın katılımcıların sayısı daha fazladır. Bu durum çalışma sonuçlarının erkek öğretmen adaylarına genellenmesinde bir sınırlılık oluşturabilmektedir.

Araştırmadan elde edilen bulgular ışı̆̆ında araştırmacılara gelecekte yapılacak çalışmalar için bazı öneriler sunmak da mümkündür. Öğretmen adayları ya da mesleğe yeni başlayan öğretmenlerle sağlıkı iletişim becerileri üzerinde çalışmak oldukça değerlidir. Nitekim sosyal ve duygusal açıdan yetkin öğretmenler öğrencileriyle destekleyici ve cesaretlendirici ilişkiler geliştirip öğrencilerin güçlü yanlarını, yeteneklerini, içsel motivasyonu teşvik edecek sınıf iklimi yaratabilir, çatışma durumlarında öğrencilere rehberlik edebilir ve iyi bir rol model olabilirler (Jennings ve Greenberg, 2009). Bu çalışmada sağı/ılı bir iletişim becerisi olan güvengenlik becerisi ile içsel kaynakları yansıtan temel psikolojik ihtiyaçlar ve bilinçli farkındalık değişkenleri incelenmiştir. Yapılacak çalışmalar çevresel ve bağlamsal değişkenleri de hesaba katabilir. Ayrıca güvengenlik üzerinde korelasyonel ve deneysel çalışmalar ile kesitsel desenler görece daha fazla iken nitel çalışmalar ve boylamsal desenler yok denecek kadar azdır. ileride yapılacak çalışmalar desen çeşitlenmesini de göz önünde bu konudaki bilgi alanına katkı sağlayabilir.

Araştırma sonuçlarına dayanarak üniversite psikolojik danışma birimlerinin önemini vurgulamak gerekir. Bu birimlerde, üniversitelerin ilk yılındaki öğrenciler için oryantasyon çalışmalarının yapılması, güvengenlik becerilerine yönelik çeşitli psikoeğitim programları ve kişilerarası ilişkilere odaklanan grupla psikolojik danışma çalışmaların önemli olduğu söylenebilir. Böylece genç yetişkinlerin öz farkındalıklarını artırmaları ve ilişkim kurma becerilerini geliştirmeleri kolaylaşabilir. Özbelirleme kuramının temel hedefleri hem bireysel hem de toplumsal düzeyde sağlıklı gelişimi ve iyi oluşu artırabilecek faktörleri belirlemektir (Cihangir-Çankaya, 2009b). Bu açıdan bakıldığında üniversite gençliğinin ve geleceği yetiştirecek olan öğretmen adaylarının kişisel gelişimine katkı sunması, kendi karar ve sorumluluğunu alabilmesi, istek ve ihtiyaçlarını uygun bir şekilde karşılayabilmesi ve bunları doğru bir iletişim çerçevesinde yürütmesi çok önemlidir. Tüm bunların toplamı güvengen davranışlar sergilemenin birer göstergesidir. Ayrıca güvengenlik gibi sosyal beceri kazandırma odaklı psikoeğitim çalışmalarında çoğunlukla Bilişsel Davranışçı ya da Davranış̧ı Yaklaşımın ilkelerine uygun olarak hazırlandığı görülmektedir (Parmaksız, 2019; Uz Baş, 2010). Araştırmanın bulgularında da hareketle psikoeğitim programlarında bilinçli farkındalık temelli programların ilke ve müdahalelerinden de 
yararlanılabilir. Bu programlarda temel psikolojik ihtiyaçlarını fark etmeleri ve doyum sağlamalarına ilişkin kazanımlara yer verilmesi de etkili olabilir. Ayrıca planlanabilecek etkileşim grupları ya da psikolojik danışma gruplarında, grubun kompozisyonu temel psikolojik ihtiyaçlarına doyum sağlayabilme üzerine temellendirilebilir. Yani bireylerin özerk kararlar verebilmesine olanak tanıyan özerkliği destekleyici bir grup ortamı, beceriler kazandırarak bunları kullanmaları yönünde cesaretlendiren ve böylece yeterlik duygusunu artırmaya çalışan ayrıca olumlu ve güvene dayalı bir grup ortamı inşa ederek aidiyet ve bağlılık duygusu edinmeye olanak tanıyan bir grup yapısı planlanabilir. 


\section{Kaynakça}

Bacanlı, H. ve Çankaya-Cihangir, Z. (2003, Temmuz). Ihtiyaç doyum ölçeği uyarlama çalışması. VII. Ulusal Psikolojik Danışma ve Rehberlik Kongresine Sunulmuş Bildiri. (s. 37-38), Malatya. (9-11 Temmuz 2003).

Brown, K. W. ve Ryan, R. M. (2003). The benefits of being present: Mindfulness and its role in psychological wellbeing. Journal of Personality and Social Psychology, 84(4), 822-848.

Brown, K. W., Ryan, R. M. ve Creswell, J. D. (2007). Mindfulness: Theoretical foundations and evidence for its salutary effects'. Psychological Inquiry, 18(4), 211-237. doi: 10.1080/10478400701598298

Can, A. (2014). Spss ile bilimsel araştırma sürecinde nicel veri analizi. (2. bs.). Ankara: Pegem Akademi.

Carstensen, B. ve Klusmann, U. (2020). Assertiveness and adaptation: Prospective teachers' social competence development and its significance for occupational well-being. British Journal of Educational Psychology. 2-27. doi:10.1111/bjep.12377

Chang, J., Huang, C. ve Lin, Y. (2015). Mindfulness, basic psychological needs fulfillment, and well-being. Journal of Happiness Studies, 16(5), 1149-1162. doi: 10.1007/s10902- 014-9551-2.

Cihangir-Çankaya, Z. (2009a). Öğretmen adaylarında temel psikolojik ihtiyaçların doyumu ve iyi olma. Türk Eğitim Bilimleri Dergisi, 7(3), 691-711.

Cihangir-Çankaya, Z. (2009b). Özerklik desteği, temel psikolojik ihtiyaçların doyumu ve öznel iyi olma: Özbelirleme Kuramı. Türk Psikolojik Danışma ve Rehberlik Dergisi, 4(31), 23-31.

Coffey, K. A. ve Hartman, M. (2008). Mechanisms of action in the inverse relationship between mindfulness and psychological distress. Complementary Health Practice Review, 13(2), 79-91. doi: 10.1177/1533210108316307.

Corey, G. (2015). Psikolojik danışma kuram ve uygulamaları. (T. Ergene, Çev.) (8. bs.). Ankara: Mentis Yayıncılık.

Costa, S., Ntoumanis, N. ve Bartholomew, K.J. (2015). Predicting the brighter and darker sides of interpersonal relationships: Does psychological need thwarting matter? Motiv. Emot., 39, 11-24. doi: 10.1007/s11031014-9427-0.

Cüceloğlu, D. (2014). Insan insana. (50. bs.). İstanbul: Remzi Kitabevi.

Deci, E. L. ve Ryan, R. M. (2000). The "what" and "why" of goal pursuits: Human needs and the self-determination of behavior. Psychological Inquiry, 11, 227-268.

Deci, E. ve Ryan, R. (2013). The importance of autonomy for development and well-being. B. Sokol, F. Grouzet, ve U. Müller (Ed.), Self-regulation and autonomy: Social and developmental dimensions of human conduct (s. 19-46) içinde. Cambridge: Cambridge University Press. doi:10.1017/CBO9781139152198.005.

Dekeyser, M., Raes, F., Leijssen, M., Leysen, S. ve Dewulf, D. (2008). Mindfulness skills and interpersonal behavior. Personality and Individual Differences, 44, 1235-1245. doi: 10.1016/j.paid.2007.11.018.

Dorman, E. (2015). Building teachers' social-emotional competence through mindfulness practices. Curriculum and Teaching Dialogue, 17(1-2), 103-119.

Erikson, E. H. (1980). Identity and life cycle. New York: W. W. Norton \& Company, Inc.

Frewen, P., Evans, E., Maraj, N., Dozois, D. ve Partridge, K. (2007). Letting go: Mindfulness and negative automatic thinking. Cognitive Therapy and Research, 32, 758-774.

Germer, C. K. ve Neff, K. D. (2013). Self-compassion in clinical practice. Journal Of Clinical Psychology: In Session, 69(8), 1-12. doi: 10.1002/Jclp.22021.

Jennings, P. A. ve Greenberg, M. T. (2009). The prosocial classroom: Teacher social and emotional competence in relation to student and classroom outcomes. Review of Educational Research, 79, 491-525. doi: 10.3102/0034654308325693

Jones, S. M., Bodie, G. D. ve Hughes, S. D. (2019). The impact of mindfulness on empathy, active listening, and perceived provisions of emotional support. Communication Research, 46(6), 838-865. doi: $10.1177 / 0093650215626983$

Jones, S.M. ve Hansen, W. (2015). The impact of mindfulness on supportive communication skills: Three exploratory studies. Mindfulness, 6, 1115-1128. doi: 10.1007/s12671-014-0362-7

Kabat-Zinn, J. (2003). Mindfulness-based interventions in context: Past, present, and future. Clinical Psychology: Science and Practice, 10(2), 144-153. doi: 10.1093/clipsy/bpg016

Keng, S. L., Smoski, M. J. ve Robins, C. J. (2011). Effects of mindfulness on psychological health: a review of empirical studies. Clinical Psychology Review, 31(6), 1041-1056. doi: 10.1016/j.cpr.2011.04.006

Kermen, U. ve Sarı, T. (2014). Üniversite öğrencilerinde ihtiyaç doyumu ve öznel iyi oluş arasındaki ilişkinin incelenmesi. Abant İzet Baysal Üniversitesi Eğitim Fakültesi Dergisi, 14(2), 175-185. 
Klassen, R. M., Perry, N. E. ve Frenzel, A. C. (2012). Teachers' relatedness with students: An underemphasized component of teachers' basic psychological needs. Journal of Educational Psychology, 104(1), $150-165$. doi: $10.1037 / a 0026253$

Kocayörük, E. (2012). Öz-belirleme kuramı açısından ergenlerin anne baba algısı ile duyuşsal iyi oluşları arasındaki ilişki. Türk Psikolojik Danışma ve Rehberlik Dergisi, 4(37), 24-37.

Neff, K. D. (2003). The development and validation of a scale to measure self compassion. Self and Identity, 2, 223- 250. doi: 10.1080/15298860390209035

Ögel, K. (2015). Farkındalık (ayrımsama) ve kabullenme temelli terapiler bilişsel davranışçı psikoterapilerde üçüncü dalga. (2. bs.). Ankara: HYB Yayıncılık.

Özdemir, Y. ve Çok, F. (2011). Ergenlikte özerklik gelişimi. Türk Psikolojik Danışma ve Rehberlik Dergisi, 4(36), $152-$ 164.

Özyeşil, Z., Arslan, C., Kesici, Ş. ve Deniz, M. E. (2011). Bilinçli Farkındalık Ölçeği'ni Türkçe'ye uyarlama çalışması. Eğitim ve Bilim, 36(160), 226-227.

Parmaksız, i. (2019). The Effect of Assertiveness Psychoeducation Program on increasing the assertiveness of university students. Sakarya University Journal of Education, 9(1), 21-32. doi: 10.19126/suje.430095.

Rubin, K. H. ve Rose-Krasnor, L. (1992). Interpersonal problem solving and social competence in children. V. B. van Hasselt ve M. Hersen (Ed.), Handbook of social development (s. 283-323) içinde. Boston, MA: Springer US. doi: 10.1007/978-1-4899-0694-6_12

Ryan, R. M. ve Deci, E. L. (2000). Self-determination theory and the facilitation of intrinsic motivation, social development, and well-being. American Psychologist, 55(1), 68-78. doi: 10.1037/0003-066X.55.1.68

Ryan, R. M. ve Deci, E. L. (2002). Overview of self-determination theory: An organismic dialectical perspective. E. L. Deci ve R. M. Ryan (Ed.), Handbook of self-determination research (s. 3-33) içinde. Rochester, NY: University of Rochester Press.

Ryan, R. M. ve Deci, E. L. (2017). Self-determination theory: Basic psychological needs in motivation, development, and wellness. New York: Guilford Publishing.

Ryan, R., Huta, V. ve Deci, E.L. (2008). Living well: a self-determination theory perspective on eudaimonia. J Happiness Stud, 9, 139-170. doi: 10.1007/s10902-006-9023-4

Santrock, J. W. (2014). Ergenlik-adolescence. (D. M. Siyez, Çev.). (14. bs.). Ankara: Nobel Akademik Yayıncılık.

Schmidt, J., Klusmann, U., Lüdtke, O., Möller, J. ve Kunter, M. (2017). What makes good and bad days for beginning teachers? A diary study on daily uplifts and hassles. Contemporary Educational Psychology, 48, 85-97.

Soysal, A. Ş., Bodur, Ş. ve Hızlı, G. (2005). Şimdi ve burada terapisi. Anadolu Psikiyatri Dergisi, 6(4), 274-280.

Thomas, C. (2011). A review of the relationships between mindfulness, stress, coping styles and substance use among university student. (Yayımlamamış doktora tezi), Edith Cowan University, Australia.

Toprak, H. (2014). Ergenlerde mutluluk ve yaşam doyumunun yordayıcısı olarak psikolojik sağlamlık ve psikolojik ihtiyaç doyumu. (Yayımlanmamış Yüksek Lisans Tezi), Sakarya Üniversitesi, Sakarya.

Uz-Baş, A. (2010). Sınıf-temelli bir sosyal beceri eğitimi programının ilköğretim dördüncü sınıf öğrencilerinin güvengenlik ve saldırganlık düzeyleri üzerindeki etkisi. Uluslararası Insan Bilimleri Dergisi, 7(2), 731-747.

Uz-Baş, A. (2012). Kişilerarası ilişkiler ve iletişimde güvengenlik. A. Kaya (Ed.), Kişilerarası ilişkiler ve etkili iletişim. (s. 174-194) içinde. Ankara: Pegem Akademi Yayıncılık.

Vansteenkiste, M., Ryan, R.M. ve Soenens, B. (2020). Basic psychological need theory: Advancements, critical themes, and future directions. Motiv Emot, 44, 1-31. doi: 10.1007/s11031-019-09818-1.

Voltan, N. (1980). Grupla atılganlık eğitiminin bireyin atılganlık düzeyine etkisi. Yayınlanmamış Doktora Tezi, Hacettepe Üniversitesi, Sosyal Bilimler Enstitüsü, Ankara.

Voltan-Acar, N., Arıcıoğlu, A., Gültekin, F. ve Gençtanırım, D. (2008). Üniversite öğrencilerinin güvengenlik düzeylerinin incelenmesi. Hacettepe Üniversitesi Eğitim Fakültesi Dergisi, 35, 342-350.

Voltan-Acar, N. ve Öğretmen, T. (2007). Kendini Belirleme (Güvengenlik) Ölçeği geliştirme çalışmaları. Türk Psikolojik Danışma ve Rehberlik Dergisi, 3(27), 67-78.

Weinstein, N., Brown, K. W. ve Ryan, R. M. (2009). A multi-method examination of the effects of mindfulness on stress attribution, coping, and emotional well-being. Journal of Research in Personality, 43(3), 374385. doi: 10.1016/j.jrp.2008.12.008

Weinstein, N. ve DeHaan, C. R. (2014). On the mutuality of human motivation and relationships. N. Weinstein (Ed.), Human motivation and interpersonal relationships: Theory, research, and applications (s. 8-25) içinde. Springer, Dordrecht. doi: 10.1007/978-94-017-8542-6 
Zhukov, M. (2020). Assertiveness training therapy to adolescence development. International Journal of Science and Society, 2(3), 50-58. doi: 10.200609/ijsoc.v2i3.126. 